PAWEŁ WAJDA

https://doi.org/10.33995/wu2021.4.1

\title{
Interwencja produktowa Komisji Nadzoru Finansowego z art. 17 ust. 1 Rozporządzenia 1286/2014 - wybrane aspekty proceduralnoprawne
}

Komisja Nadzoru Finansowego, jako organ nadzoru nad rynkiem ubezpieczeniowym, została upoważniona do stosowania środka nadzorczego w postaci interwencji produktowej. Instrument ten jest nakierowany na wyeliminowanie negatywnych zjawisk występujacych w obrębie określonego sektora ubezpieczeń. Wskazać należy, że ze względu na ograniczonq regulację decyzji w przedmiocie interwencji produktowej w art. 17 Rozporzqdzenia PRIIP oraz w art. 366 ustawy z dnia 11 września 2015 roku o działalności ubezpieczeniowej i reasekuracyjnej, zwłaszcza w zakresie wymogów, jakie powinna ona spełniać, powstaje pytanie, czy właściwy organ nadzoru nad rynkiem ubezpieczeniowym upoważniony jest nie tylko do wydania czy cofnięcia interwencji produktowej, ale również do zmiany takiej decyzji. W tym kontekście szczególnie interesujqce jest to, czy organ nadzoru nad rynkiem ubezpieczeniowym posiada kompetencję do zmiany terminu zawieszajqcego określonego w treści decyzji Komisji Nadzoru Finansowego z dnia 15 lipca 2021 roku wprowadzajacej zakazy wprowadzania do obrotu, dystrybucji i sprzedaży ubezpieczeniowych produktów inwestycyjnych - umów ubezpieczenia na życie, jeżeli sq zwiqzane z ubezpieczeniowym funduszem kapitałowym.

Słowa kluczowe: termin, interwencja produktowa, aspekty proceduralnoprawne, akt generalny, Komisja Nadzoru Finansowego.

\section{Wprowadzenie}

Komisja Nadzoru Finansowego, jako organ sprawujący nadzór nad prawidłowym funkcjonowaniem rynku finansowego, zgodnie z regulacją krajowa (tj. normą z art. 366 ustawy z dnia 11 września 
2015 roku o działalności ubezpieczeniowej i reasekuracyjnej ${ }^{1}$ J została upoważniona do stosowania nadzwyczajnego środka nadzorczego w postaci interwencji produktowej ${ }^{2}$. Zastosowanie tego środka nadzorczego przez KNF skutkować może wycofaniem wprowadzonych do obrotu, dystrybucji lub sprzedaży konkretnych produktów inwestycyjnych lub produktów inwestycyjnych o określonych cechach albo zakazem prowadzenia szczególnego rodzaju działalności finansowej lub praktyki stosowanej przez podmiot świadczący usługi na rynku finansowym. Środek nadzoru powinien być stosowany przez właściwy organ nadzoru nad rynkiem ubezpieczeniowym - z jednej strony z uwzględnieniem zasady proporcjonalności, a z drugiej - w celu zapewnienia ochrony inwestorów (konsumentów) oraz wyeliminowania zakłóceń w funkcjonowaniu rynku ubezpieczeniowego ${ }^{3}$. Możliwość wprowadzenia przez KNF do obrotu prawnego decyzji w przedmiocie interwencji produktowej stanowi formę mitygacji ryzyk systemowych powstających na rynku finansowym. Jednocześnie stosowanie interwencji produktowej należy uznać za realizację konstytucyjnej zasady ochrony konsumentów (w odniesieniu do inwestorów detalicznych, którzy nie złożyli wniosku w przedmiocie traktowania ich jak inwestorów profesjonalnych]. W szczególności celem wprowadzenia interwencji produktowej jest ochrona inwestorów rynku ubezpieczeniowego poprzez eliminację poważnych zagrożeń dotyczących prawidłowego funkcjonowania i integralności rynków finansowych lub stabilności całego systemu finansowego lub części tego systemu. Omawiana instytucja ma także na celu wyrównanie zaistniałych na rynku nierówności, zgodnie z dyrektywą dążenia do urzeczywistnienia stabilności finansowej na rynku ${ }^{4}$. Decyzja w przedmiocie interwencji produktowej wydana przez KNF stanowić ma środek skutecznego oraz sprawnego przeciwdziałania nieprawidłowościom istniejącym na rynku i negatywnie oddziałującym na sferę ochrony praw inwestorów (konsumentów) działających na tym rynku ${ }^{5}$.

Wydanie decyzji Komisji Nadzoru Finansowego z dnia 15 lipca 2021 roku (sygn. DNMDNMZWP.6065.79.2021) w sprawie wprowadzenia zakazu w przedmiocie wprowadzenia do obrotu, dystrybucji i sprzedaży ubezpieczeniowych produktów inwestycyjnych - umów ubezpieczenia na życie z art. 17 ust. 1 lit. a) Rozporządzenia Parlamentu Europejskiej i Rady (UE) Nr 1286/2014 z dnia 26 listopada 2019 roku w sprawie dokumentów zawierających kluczowe informacje, dotyczących detalicznych produktów zbiorowego inwestowania i ubezpieczeniowych produktów inwestycyjnych ${ }^{6}$ ma istotny wpływ dla polskiego sektora ubezpieczeniowego. Dlatego też autor niniejszej publikacji postanowił dokonać analizy praktyki orzeczniczej na tle stosowania tej regulacji, sposobu interpretacji przepisów dotyczących interwencji produktowej oraz dorobku doktryny wypracowanego w tym zakresie. Za szczególnie interesującą kwestię należy przy tym uznać możliwość zmiany przez KNF zastrzeżonego terminu zawieszającego w treści decyzji w przedmiocie

1. Tekst jedn. Dz. U. 2021, poz. 1130, z późn. zm.; dalej: u.dz.u.r.

2. Wyrok WSA w Warszawie z dnia 20.11.2018 r., sygn. II SA/Wa 728/18, LEX nr 2757847.

3. J. Łańcucki, Interwencja produktowa jako instrument ochrony konsumentów w sektorze ubezpieczeń, [w:] Ubezpieczenia we współczesnym świecie. Problemy i tendencje, [red.] I. Kwiecień, Wydawnictwo Uniwersytetu Ekonomicznego we Wrocławiu, Wrocław 2017, s. 128-136.

4. B. Mrozowska-Bartkiewicz, Instytucja interwencji produktowej w Europejskim Systemie Nadzoru Finansowego, „Prawo Asekuracyjne” 2019, nr 1, s. 42-54; A. Piotrowska, Ochrona klientów na rynku ubezpieczeniowym. Studium publicznoprawne, Wydawnictwo Naukowe Scholar, Warszawa 2019.

5. P. Brzuszczak, K. Ferenc, Charakter prawny aktu administracyjnego generalnego: przełom w dyskusji?, „Studia Prawnicze i Administracyjne" 2013, nr 2, s. 46.

6. Tekst jedn. Dz. Urz. UE L 352 z 9 grudnia 2014, s. 1 i nast., z późn. zm.; dalej: Rozporządzenie PRIIP. 
wprowadzenia zakazów lub ograniczeń określonych w art. 17 Rozporządzenia PRIIP. W treści decyzji z dnia 15 lipca 2021 roku KNF wskazała fakultatywny element w postaci terminu zawieszającego, zaznaczając, iż decyzja obowiązuje od dnia 1 stycznia 2022 roku. Celem niniejszej publikacji jest (dokonana w oparciu o dorobek doktryny, orzecznictwa sądów administracyjnych, jak również wykładni przepisów prawa] analiza tego, czy KNF mogłaby dokonać zmiany decyzji KNF z dnia 15 lipca 2021 roku, w szczególności w zakresie zmiany terminu zawieszającego określonego w tej decyzji.

\section{Charakter decyzji w przedmiocie interwencji produktowej}

W pierwszej kolejności, odnosząc się do decyzji KNF, o której mowa w art. 366 ust. 2 u.dz.u.r. zauważyć warto, iż nie jest ona decyzją administracyjną w rozumieniu art. 1 pkt 1 i 2 w związku z art. 104 ustawy z dnia 14 czerwca 1960 roku - Kodeks postępowania administracyjnego?, jak również nie jest aktem normatywnym ${ }^{8}$. Wskazać bowiem należy, że decyzja KNF w przedmiocie interwencji produktowej na rynku ubezpieczeniowym nie stanowi rozstrzygnięcia w sprawie indywidualnej ( $t$ j. dotyczącej konkretnego stanu faktycznego) indywidualnie określonego adresata (tj. imiennie określonego adresata) w rozumieniu art. 1 pkt 1 i 2 k.p.a. Przedmiotowa decyzja nie jest adresowana do indywidualnego odbiorcy, ale skierowana do wszystkich krajowych zakładów ubezpieczeń, które w swojej ofercie posiadaja produkty ubezpieczeniowe wskazane w treści decyzji KNF z dnia 15 lipca 2021 roku. Dodatkowo zauważyć należy, że ustawodawca w treści przepisu z art. 366 ust. 3 u.dz.u.r. explicite wskazał: „do decyzji, o których mowa w ust. 2, przepisy ustawy z dnia 14 czerwca 1960 roku - Kodeks postępowania administracyjnego stosuje się odpowiednio". W przypadku, gdyby ustawodawca zamierzał podkreślić, że decyzja z art. 366 ust. 2 u.dz.u.r. jest decyzją administracyjną, to przepis z art. 366 ust. 3 u.dz.u.r. stanowiłby w istocie wyraz tzw. superfluum ustawowego, ponieważ przepisy k.p.a. znajdowałyby zastosowanie wprost do takiej decyzji administracyjnej. A zatem okoliczność tę należy postrzegać in favorem tego, że decyzja w przedmiocie stosowania interwencji produktowej powinna być zaliczona do aktów o charakterze generalnym i nie może podlegać kwalifikacji jako decyzja administracyjna.

Oznacza to, że decyzja KNF wydana w oparciu o art. 17 Rozporządzenia PRIIP w związku z art. 366 u.dz.u.r. - w rozumieniu katalogu prawnych form działania administracji - podlegać będzie kwalifikacji jako akt administracyjny generalny ${ }^{9}$. Generalny akt administracyjny charakteryzuje się m.in.

7. Tekst jedn. Dz. U. 2021, poz. 735, z późn. zm.; dalej: k.p.a.

8. W zakresie szczegółowego omówienia różnic pomiędzy generalnym aktem administracyjnym, aktem normatywnym a decyzją administracyjną zgodzić się należy z rozważaniami zawartymi w: M. Szewczyk, E. Szewczyk, Generalny akt administracyjny, Wolters Kluwer, Warszawa 2014; W. Chróścielewski, Akt administracyjny generalny, Wydawnictwo Uniwersytetu Łódzkiego, Łódź 1994, s. 5, 83 i nast. oraz s. 98 i nast.; J. Filipek, Podział na indywidualne i generalne akty administracyjne, [w:] Administracja publiczna u progu XXI wieku. Prace dedykowane prof. zw. dr. hab. Janowi Szreniawskiemu z okazji jubileuszu 45-lecia pracy naukowej, [red.] Z. Niewiadomski, J. Buczkowski, J. Łukasiewicz, J. Posłuszny, J. Stelmasiak, Wydawnictwo Wyższej Szkoły Administracji i Zarządzania, Przemyśl 2000, s. 181 i nast.; M. Smaga, Generalne akty administracyjne regulujqce prawa i obowiqzki użytkownika drogi publicznej (znaki drogowe) - wybrane zagadnienia, [w:] Instytucje współczesnego prawa administracyjnego. Księga jubileuszowa Profesora zw. dra hab. Józefa Filipka, [red.] I. Niżnik-Dobosz, P. Dobosz, D. Dąbek, M. Smaga, Wydawnictwo Uniwersytetu Jagiellońskiego, Kraków 2001, s. 635 i nast.

9. M. Szewczyk, E. Szewczyk, Generalny akt administracyjny, Wolters Kluwer, Warszawa 2014. 
tym, że skierowany jest do wielu adresatów, którzy znajdują się w tożsamym stanie faktycznym i stanie prawnym. Przekładając wskazane okoliczności na grunt przepisu z art. 366 u.dz.u.r., wskazać należy, że adresatem decyzji KNF w przedmiocie interwencji produktowej jest każdy podmiot, do którego skierowany został przez KNF zakaz, o którym mowa wart. 17 ust. 1 Rozporządzenia PRIIP. Zauważyć bowiem trzeba, jak słusznie wskazuje się w piśmiennictwie, że za przedmiot generalnego aktu administracyjnego należy przyjać ustalenie sytuacji prawnej (w zakresie uprawnień czy zobowiązań) generalnego adresata w konkretnej sytuacji (wystapienia jednolitych okoliczności dotyczących wielu adresatów). Generalne akty administracyjne ujmuje się jako formę pośrednią działania organów administracyjnych, która zawiera w sobie elementy charakterystyczne dla aktów administracyjnych (indywidualno-konkretnych) oraz elementy właściwe dla aktów normatywnych (generalno-abstrakcyjnych). Jako cechę generalnych aktów administracyjnych wskazuje się w doktrynie możliwość podjęcia przez organ stosownych działań w związku z wystapieniem niekorzystnych zjawisk czy zagrożeń pojawiających się w obrocie publicznym ${ }^{10}$.

Akt generalny zakwalifikować należy jako formę konkretyzacji prawa administracyjnego materialnego, która następuje z pominięciem etapu jurysdykcji, (tj. z pominięciem sformalizowanej procedury administracyjnej ${ }^{11}$. Możliwość wydania generalnego aktu administracyjnego uwarunkowana jest przy tym koniecznością istnienia ustawowej normy kompetencyjnej do wydania tego typu aktu ${ }^{12}$. Oznacza to, że organ wydający generalny akt administracyjny jest zobowiązany do uwzględnienia wszelkich okoliczności oraz elementów, które zostały wskazane w przepisach prawa materialnego i maja zastosowanie do aktu generalnego wydawanego przez dany organ. W zakresie natomiast elementów nieokreślonych w przepisach prawa materialnego KNF (czy inny właściwy organ) dysponuje władzą dyskrecjonalną. Akty te określane są w piśmiennictwie także jako wynik autonomii władzy wykonawczej w systemie trójpodziału władzy czy rezultat konieczności prowadzenia bieżących spraw państwa, poparty interesem publicznym ${ }^{13}$.

Wydanie przez KNF decyzji w przedmiocie interwencji produktowej należy uznać za działanie nakierowane na ochronę przed zagrożeniem dla prawidłowego funkcjonowania i integralności rynków finansowych lub stabilności całego systemu finansowego Unii Europejskiej lub jego części. Granice tego działania wyznacza treść przepisów prawa materialnego przewidujących kompetencję dla organu nadzoru do stosowania interwencji produktowej ${ }^{14}$. KNF, wydając decyzję z art. 366 u.dz.u.r., jest zobowiązana do przestrzegania zakresu kompetencyjnego, jaki został określony w przepisach Rozporządzenia PRIIP oraz u.dz.u.r., a także powinna odpowiednio stosować przepisy k.p.a.

W tym kontekście warto przytoczyć stanowisko EIOPA, w którym słusznie zauważono, że za kluczowe należy uznać możliwość dynamicznej realizacji uprawnień przysługujących krajowym organom

10. J. Chmielewski, [w:] /us est a iustitia appellatum. Księga jubileuszowa dedykowana Profesorowi Tadeuszowi Wiśniewskiemu, [red.] T. Ereciński, J. Gudowski, M. Pazdan, M. Tomalak, Wolters Kluwer, Warszawa 2017, s. 1095-1117; por. także: W. Chróścielewski, Akt administracyjny generalny, Wydawnictwo Uniwersytetu Łódzkiego, Łódź 1994, s. 105.

11. T. Woś, [w:] Postępowanie sqdowoadministracyjne, [red.] T. Woś, Wolters Kluwer, Warszawa 2017, s. 54; D. Kijowski, Generalny akt stosowania prawa w ustawodawstwie polskim, „Przegląd Legislacyjny” 2014, nr 3, s. 9-30.

12. M. Wiącek, [w:] Konstytucja RP. Tom II. Komentarz do art. 87-243, [red.] M. Safjan, L. Bosek, CH Beck, Warszawa 2016, Legalis, komentarz do art. 87 Konstytucji RP.

13. M. Kulesza, 0 tym, ile jest decentralizacji w centralizacji, a także o osobliwych nawykach uczonych administratywistów, „Samorząd Terytorialny” 2009, nr 12, s. 9.

14. Analogicznie: Wyrok Trybunału Sprawiedliwości Unii Europejskiej z 22.01.2014 r. w sprawie C-270/12, Zjednoczone Królestwo Wielkiej Brytanii i Irlandii Północnej przeciwko Parlamentowi Europejskiemu i Radzie Unii Europejskiej, Curia. 
właściwym w sprawie ochrony konkurencji, a także - w sytuacji wystapienia szczególnych okoliczności - możliwość podjęcia przez europejskie organy nadzoru niezwłocznych i dostosowanych do sytuacji działań, mających na celu skuteczne ograniczenie występowania w sektorze ubezpieczeniowym niepożądanych zjawisk. Europejski Urząd Nadzoru Ubezpieczeń i Pracowniczych Programów Emerytalnych ${ }^{15}$ zauważył, że elastyczność rozpoczęcia oraz prowadzenia działań zarówno przez krajowe, jak i europejskie organy nadzoru w zakresie podejmowania interwencji produktowej jest kluczowa. W tym kontekście EIOPA wskazał, że to właściwy organ nadzoru powinien niejako na podstawie własnego uznania (w zakresie przyznanej władzy dyskrecjonalnej) dojść do wniosku, iż zastosowanie środka w postaci interwencji produktowej będzie zasadne, nawet jeżeli spełnione zostały niektóre z kryteriów określonych w przepisie z art. 17 Rozporządzenia PRIIP, jednakże nie stwierdzono zaistnienia „ogólnej szkody dla konsumentów lub zakłóceń w funkcjonowaniu rynków”16. Tym samym EIOPA zwrócił szczególną uwagę na znaczenie elastyczności w zakresie stosowania (lub odstapienia od stosowania interwencji produktowej] działań interwencyjnych przez organy nadzoru państw członkowskich. Takie stanowisko z kolei przemawia za przyjęciem, że organ nadzoru działa zgodnie ze swoim uznaniem w zakresie nieuregulowanym w przepisach prawa materialnego. EIOPA bowiem zauważył, że to organ nadzoru państwa członkowskiego władny jest podjać decyzję o zasadności stosowania interwencji produktowej w sposób elastyczny. W efekcie przyjąć należy, że skoro organ nadzoru państwa członkowskiego uprawniony jest do podjęcia decyzji o zastosowaniu interwencji produktowej, to organ ten uprawniony jest również do zmiany treści takiej decyzji, w tym w szczególności zmiany terminu zawieszającego, o ile uzna, iż takie działanie jest uzasadnione i dostosowane do sytuacji istniejącej w konkretnym, krajowym sektorze ubezpieczeniowym.

\section{Termin dotyczący obowiązywania interwencji produktowej}

W treści Rozporządzenia PRIIP oraz przepisach u.dz.u.r. nie określono terminu, w jakim decyzja w przedmiocie zastosowania interwencji produktowej powinna obowiazywać (podobnie nie wskazano, czy organ nadzoru uprawniony jest do wprowadzenia do decyzji terminu zawieszającego ${ }^{1}{ }^{1}$.

15. Dalej: EIOPA.

16. EIOPA, Final Report on Product Intervention Powers under the Regulation on Key Information Documents for Packaged Retail and Insurance-Based Investment Products (PRIIPS) z dnia 29.06.2015 r., EIOPA-15/569, https://www.eiopa.europa.eu/sites/default/files/publications/consultations/eiopa-15-569_final_report_on certain_criteria_for_product_intervention_p.pdf, s. 11 [dostęp: 22.11.2021].

17. Na co explicite wskazuje KNF na s. 83 decyzji KNF z dnia 15.07.2021 r. (sygn. DNM-DNMZWP.6065.79.2021) w sprawie wprowadzenia zakazu w przedmiocie wprowadzenia do obrotu, dystrybucji i sprzedaży ubezpieczeniowych produktów inwestycyjnych - umów ubezpieczenia na życie z art. 17 ust. 1 lit. a) Rozporządzenia PRIIP. Zauważyć przy tym należy, że art. 17 ust. 5 Rozporządzenia PRIIP, zgodnie z którym „Właściwy organ publikuje na swoich stronach internetowych komunikat o każdej decyzji dotyczącej nałożenia zakazu lub ograniczenia, o których mowa w ust. 1. Komunikat ten zawiera szczegóły zakazu lub ograniczenia, okres liczony od publikacji komunikatu, po upływie którego środki wchodzą w życie, a także dowody, na podstawie których organ upewnił się, że spełniony jest każdy z warunków, o których mowa w ust. 2. Zakaz lub ograniczenie mają zastosowanie tylko do działań podejmowanych po opublikowaniu komunikatu", reguluje elementy, jakie powinien zawierać komunikat w sprawie wydania decyzji w przedmiocie interwencji produktowej. Nie można uznać art. 17 ust. 5 Rozporządzenia PRIIP za przepis wyznaczający elementy, które powinny zostać ujęte $w$ treści decyzji z art. 366 ust. 2 u.dz.u.r. 
W przepisach Rozporządzenia PRIIP zapisano jedynie, że planowany moment wejścia w życie interwencji produktowej powinien być oznaczony jako konkretna data w przyszłości. Nie musi to być zatem data wydania decyzji w przedmiocie zastosowania interwencji produktowej, która podlega określeniu przez organ nadzoru państwa członkowskiego. Powyższe strzeżenie znajduje potwierdzenie w odniesieniu do interwencji produktowych wprowadzanych przez Europejski Urząd Nadzoru Giełd i Papierów Wartościowych czy KNF w zakresie interwencji dotyczących opcji binarnych, gdzie data wejścia w życie interwencji produktowej określana jest przez organ w sposób autonomiczny, niesprecyzowany przez przepisy prawa. W praktyce obrotu KNF, wydając decyzję z dnia 25 czerwca 2019 roku w sprawie zakazu wprowadzania do obrotu, dystrybucji lub sprzedaży klientom detalicznym opcji binarnych ${ }^{18}$, określiła, że zacznie ona obowiązywać od dnia 2 lipca 2019 roku. Podobnie Europejski Urząd Nadzoru Giełd i Papierów Wartościowych również w wydawanych przez siebie decyzjach wprowadzających interwencje produktowe przewidywał swego rodzaju vacatio legis.

Uwzględniając charakter środka w postaci interwencji produktowej, tj. w szczególności fakt, iż stosowanie tego środka uzależnione jest od specyficznych okoliczności oraz uwarunkowań charakterystycznych dla określonego rynku ubezpieczeniowego, a także mając na względzie okoliczność działania przez KNF w granicach władzy dyskrecjonalnej, należy zauważyć, iż KNF uprawniona jest ustalić termin obowiązywania decyzji z art. 366 ust. 2 u.dz.u.r. w sposób dostosowany do indywidualnych potrzeb oraz sytuacji (konieczności zastosowania interwencji produktowej) występującej w danym momencie w obrębie konkretnego rynku ubezpieczeń. Organ nadzoru nad rynkiem ubezpieczeniowym, stosując instrument interwencji produktowej w zakresie wycofania wprowadzonych do obrotu, dystrybucji lub sprzedaży konkretnych produktów inwestycyjnych lub produktów inwestycyjnych o określonych cechach albo zabronienia prowadzenia szczególnego rodzaju działalności finansowej lub praktyki stosowanej przez podmiot świadczący usługi na rynku finansowym, decyduje, od kiedy instrument ten powinien wejść w życie. Skoro zatem KNF, działajac w ramach posiadanej władzy dyskrecjonalnej, wprowadziła do treści decyzji z dnia 15 lipca 2021 roku termin zawieszający i określiła go na dzień 1 stycznia 2022 roku, to stosując wnioskowanie prawnicze argumentum a fortiori w jego odmianie argumentum a maiori ad minus, należy przyjać, że tym bardziej dozwolone jest dokonanie zmiany tego terminu. KNF, dopuszczając zastrzeżenie elementu fakultatywnego, tj. terminu w treści decyzji wdrażającej interwencję produktową na rynku ubezpieczeniowym, niejako dopuściła również możliwość ewentualnej, następczej zmiany tak wprowadzonego terminu zawieszającego.

\section{Stosowanie przepisów k.p.a. do decyzji w przedmiocie interwencji produktowej}

W treści przepisu z art. 366 ust. 3 u.dz.u.r. ustawodawca wskazał, że KNF powinna stosować odpowiednio przepisy k.p.a. do decyzji w przedmiocie interwencji produktowej, uwzględniając okoliczności faktyczne i prawne sprawy, w której decyzja z art. 366 ust. 2 u.dz.u.r. jest wydawana. Przepisy te stosuje się w odniesieniu do decyzji w przedmiocie interwencji produktowej z uwzględnieniem odrębności wynikającej z jej charakteru, co w istocie oznacza, że odpowiednie stosowanie przepisów ustawy k.p.a. „może natomiast polegać na zastosowaniu przepisu (lub jego części) wprost,

18. Sygn. DAS.456.1.2019, Dz. Urz. KNF z 2019, poz. 18. 
z modyfikacją lub nawet na odmowie zastosowania - w zależności od specyfiki sytuacji, do której przepisy te maja być użyte"19.

W praktyce przepisy k.p.a. powinny być stosowane przez KNF w zakresie ustalenia stanu faktycznego oraz stanu prawnego (np. w zakresie postępowania wyjaśniającego czy współdziałania organów zgodnie z art. 106-106a k.p.a.), a także do mających miejsce przy wydawaniu decyzji z art. 366 ust. 1 u.dz.u.r. niektórych czynności materialno-technicznych. Ze względu na niemożność zastosowania części przepisów k.p.a. do aktów administracyjnych generalnych wskazać należy, że nie można do decyzji KNF z dnia 15 lipca 2021 roku zastosować środków prawnych przewidzianych w k.p.a. Stosowanie generalnego aktu administracyjnego uniemożliwia bowiem stosowanie przez właściwy organ konkretnych instytucji zawartych w k.p.a., majacych na celu realizację poszczególnych zasad przyświecających k.p.a. i nakierowanych na ochronę sfery interesów i praw podmiotów odznaczających się posiadaniem interesu prawnego w danych okolicznościach. Dlatego też w literaturze przypisuje się szczególne znaczenie uzasadnieniu decyzji w przedmiocie wprowadzenia interwencji produktowej, w którym znajdzie się opis stanu faktycznego i subsumcja, w szczególności w zakresie odniesienia się przez organ do kryteriów wskazanych w art. 17 ust. 2 Rozporządzenia PRIIP20. Do decyzji tej nie znajdą też zastosowania przepisy k.p.a. dotyczące doręczenia decyzji w przedmiocie interwencji produktowej ${ }^{21}$, co wynika z art. 366 ust. 4 u.dz.u.r. wskazującego na konieczność ogłoszenia takiej decyzji w Dzienniku Urzędowym KNF oraz publikację informacji o takim działaniu KNF przez właściwą agencję informacyjną.

Jakkolwiek do decyzji z art. 366 ust. 2 u.dz.u.r. zastosowania nie znajda przepisy k.p.a. normujace tzw. środki prawne (z uwagi na brak posiadania przymiotu strony postępowania przez adresatów decyzji z art. 366 ust. 2 u.dz.u.r.), to zastosowanie do tej decyzji z powodzeniem może znaleźć instytucja z art. 154 k.p.a., która stosowana jest przez KNF z urzędu (przy czym może być również stosowana na wniosek podmiotu posiadającego interes prawny). Zgodnie z art. 154 k.p.a. decyzja ostateczna, na mocy której żadna ze stron nie nabyła prawa, może być w każdym czasie uchylona lub zmieniona przez organ administracji publicznej, który ją wydał, jeżeli przemawia za tym interes społeczny lub słuszny interes strony. Za decyzję, na podstawie której nie nabyto praw, należy przy tym uznać decyzję w przedmiocie interwencji produktowej.

W piśmiennictwie wskazuje się, że art. 154 k.p.a. nie może podlegać stosowaniu w celu uchylenia lub zmiany decyzji ostatecznej, na mocy której strona nie nabyła prawa, jeżeli przepisy ustaw sprzeciwiają się zmianie lub uchyleniu takich decyzji ostatecznych lub wprowadzają wyraźny zakaz uchylania albo zmiany wszelkich decyzji ostatecznych, gdzie w przepisach dotyczacych

19. Uchwała Sądu Najwyższego z dnia 18.12.2001 r., sygn. III ZP 25/01, OSNP 2002/13/301; zob. także: wyrok NSA z dnia 25.05.2021 r., sygn. II GSK 1983/18, LEX nr 3209074; wyrok NSA z dnia 21.04.2020 r., sygn. II OSK 2371/19, LEX nr 3058941.

20. B. Wojno, [w:] Ustawa o działalności ubezpieczeniowej i reasekuracyjnej. Komentarz, [red.] M. Szczepańska, P. Wajda, Wolters Kluwer, Warszawa 2017, s. 1220-1229.

21. P. Wajda, [w:] Prawo rynku kapitałowego. Komentarz, [red.] M. Wierzbowski, L. Sobolewski, P. Wajda, CH Beck, Warszawa 2018, Legalis, komentarz do art. 32c ustawy z dnia 29 lipca 2005 r. o obrocie instrumentamifinansowymi; por. także analogicznie: A. Krawczyk, Standardy współczesnej regulacji postępowania administracyjnego, [w:] Prawo Procesowe Administracyjne. System Prawa Administracyjnego Tom 9, [red.] R. Hauser, Z. Niewiadomski, A. Wróbel, CH Beck, Warszawa 2020, Legalis; R. Mikosz, M. Zirk-Sadowski, Granice prawa do sqdu administracyjnego w Rzeczypospolitej Polskiej, „Zeszyty Naukowe Sądownictwa Administracyjnego" 2007, s. 37; wyrok WSA w Warszawie z dnia 13.04.2012 r., sygn. VII SA/Wa 2893/11, LEX nr 1275880. 
interwencji produktowej taki zakaz nie został zastrzeżony ani przez prawodawcę unijnego, ani przez polskiego ustawodawcę $e^{22}$. Instytucja z art. 154 k.p.a. znajduje także zastosowanie do decyzji uznaniowych ${ }^{23}$, a za taką należy uznać decyzję w przedmiocie interwencji produktowej. Zastosowanie art. 154 k.p.a. wymaga kumulatywnego spełnienia następujących przesłanek:

- decyzja ostateczna nie może tworzyć praw dla żadnej ze stron postępowania,

- za uchyleniem lub zmianą takiej decyzji przemawiają interes społeczny lub słuszny interes strony. KNF, oceniając, czy za zmianą lub uchyleniem decyzji ostatecznej w przedmiocie interwencji produktowej przemawia interes społeczny lub słuszny interes podmiotu, związana jest treścia przepisem z art. 7 k.p.a. Co wymaga podkreślenia, przesłanki wymagania interesu społecznego lub słusznego interesu strony muszą być ustalone w konkretnej sprawie i muszą zyskać zindywidualizowaną treść, wynikająca ze stanu faktycznego i prawnego sprawy24.

Instytucja ta - na co wskazuje trafnie organ nadzoru w opracowywanych materiałach ${ }^{25}$ - znajduje zastosowanie tak do nieprawidłowych ${ }^{26}$, jak i prawidłowych decyzji administracyjnych. Celowe w tym miejscu jest podkreślenie, że w orzecznictwie trafnie przyjmuje się, iż ,jedną z przyczyn zastosowania art. 154 k.p.a. może być zmiana wykładni prawa dokonana po wydaniu decyzji ostatecznej, a odnosząca się do podstawy prawnej wydania weryfikowanej decyzji ostatecznej [...], ponieważ celem zastosowania tego przepisu nie jest eliminowanie, na zasadzie tzw. uznania administracyjnego, decyzji administracyjnej ze względu na jej istotną wadliwość, ale ze względu na wystapienie innych przesłanek, także tych pozaprawnych"2?. W doktrynie wskazuje się, że organ administracji publicznej może zmienić lub uchylić decyzję ostateczną niezależnie od zmiany stanu prawnego czy stanu faktycznego istniejaccego w dniu wydania takiej decyzji2 ${ }^{2}$, przy czym zmiany dotyczące stanu faktycznego mogą wpływać wyłącznie na ocenę tego, czy w danej sprawie interes społeczny lub słuszny interes strony przemawiają za uchyleniem bądź zmianą decyzji dotychczasowej ${ }^{29}$. Uchylenie lub zmiana decyzji ostatecznej, na mocy której nie nabyto prawa, zgodnie z art. 154 k.p.a. może nastapić w każdym czasie.

22. A. Wróbel, [w:] Komentarz aktualizowany do Kodeksu postępowania administracyjnego, M. Jaśkowska, M. Wilbrandt-Gotowicz, A. Wróbel, Lex/el. 2021, komentarz do art. 154 k.p.a.

23. Tak np.: wyrok NSA z dnia 14.06.2005 r., sygn. OSK 1667/04, LEX nr 171686; wyrok NSA z dnia 19.10.2012 r., sygn. II OSK 1153/11, LEX nr 1234106.

24. Wyrok NSA z dnia 23.02.2007 r., sygn. I OSK 553/06, LEX nr 348253.

25. Urząd KNF, Bankjako strona postępowania administracyjnego prowadzonego przez Komisję Nadzoru Finansowego, https://www.knf.gov.pl/knf/pl/komponenty/img/Prezentacja\%20CEDUR\%2021-05-2019_6661?.pdf [dostęp: 22.11.2021].

26. W rozumieniu decyzji dotkniętych wadami niekwalifikowanymi z uwagi na niekonkurencyjność trybów nadzwyczajnych (por. np.: wyrok NSA z dnia 27.08.1999 r., sygn. I SA 1999/98, LEX nr 48660; wyrok NSA z dnia 6.11.1998 r., sygn. II SA 1185/98, LEX nr 41315; wyrok NSA z dnia 18.02.2000 r., sygn. V SA 1346/99, LEX nr 41773; wyrok NSA z 25.02.2011 r., sygn. I OSK 607/10, LEX nr 784233; wyrok NSA z dnia 14.06.2005 r., sygn. OSK 166?/04, LEX nr 171686).

27. Wyrok WSA w Łodzi z dnia 3.08.2018 r., sygn. III SA/Łd 627/18, LEX nr 2527836; wyrok NSA z dnia 9.11.2007 r., sygn. I OSK 1531/06, LEX nr 418289; wyrok NSA z dnia 27.04.2020 r., sygn. I OSK 87/19, LEX nr 3099240; wyrok NSA z dnia 18.09.2019 r., sygn. I OSK 2893/17, LEX nr 2721994; wyrok NSA z dnia 23.08.2019 r., sygn. I OSK 2525/17, LEX nr 2725211.

28. Wyrok NSA z dnia 20.12.1991 r., sygn. II SA 893/91, ONSA 1993/2, poz. 33.

29. A. Wróbel, [w: Komentarz aktualizowany do Kodeksu postępowania administracyjnego, [red.] M. Jaśkowska, M. Wilbrandt-Gotowicz, A. Wróbel, Lex/el. 2021, komentarz do art. 154 k.p.a. 
Mając także na uwadze powyższe okoliczności, należy wskazać, że KNF jest uprawniona działając na podstawie przepisu z art. 154 k.p.a. - wydać kolejny generalny akt administracyjny, na mocy którego dokona zmiany terminu zawieszającego określonego w decyzji KNF z dnia 15 lipca 2021 roku. Za pośrednie potwierdzenie powyższego stanowiska prezentowanego w judykaturze należy uznać pogląd wyrażony w piśmiennictwie przez Bartosza Wojnę, który trafnie wskazał, że zgodnie $z$ art. 366 ust. 3 u.dz.u.r. w odniesieniu do decyzji z art. 366 ust. 2 u.dz.u.r. odpowiednie zastosowanie znajduja przepisy kodeksu postępowania administracyjnego, co oznacza, że kodeks postępowania administracyjnego będzie znajdował zastosowanie nie tylko do aktu wydawanego przez organ nadzoru, ale także - do procedury wydawania tego aktu ${ }^{30}$. W tym kontekście zauważyć warto, iż odpowiednie stosowanie prawa kwalifikowane jest jako szczególna forma analogii, która może być stosowana w przypadku bezpośredniego zalecenia takiego działania przez prawodawcę w treści przepisów. Odpowiednie stosowanie przepisów prawa polegać może przy tym na zastosowaniu właściwego przepisu wprost, z odpowiednimi zmianami lub brakiem zastosowania przepisu w ogólności ${ }^{31}$, co zależne jest od wykładni systemowej a także funkcjonalnej ${ }^{32}$, czy również od rodzaju postępowania ${ }^{33}$. Nie będzie przy tym możliwe, aby organ korzystał z formy generalnego aktu administracyjnego z jednoczesnym zapewnieniem realizacji np. zasady czynnego udziału strony, przekonywania czy ugodowego załatwiania spraw ${ }^{34}$. W piśmiennictwie nie wyłączono jednakże możliwości zastosowania instytucji z art. 154 k.p.a. do generalnych aktów administracyjnych wydawanych przez KNF, wobec czego zauważyć należy, iż KNF może skorzystać z tej instytucji w celu zmiany decyzji w przedmiocie interwencji produktowej.

\section{Uprawnienie KNF do zmiany terminu zawieszającego określonego w interwencji produktowej}

Mając na uwadze powyższe rozważania, wskazać należy, że o ile KNF zidentyfikowałaby potrzebę zmiany terminu zawieszającego określonego w treści decyzji w przedmiocie interwencji produktowej, to KNF jak najbardziej posiada takie uprawnienie i tym samym uprawniona jest do wydania decyzji zmieniającej uprzednią decyzję w przedmiocie interwencji produktowej, w której zostanie wskazany zmieniony termin zawieszający. Ustawodawca dopuścił w sposób wyraźny możliwość dokonania takiej zmiany w przepisach prawa dla decyzji administracyjnych (argumentum ex art. 154 k.p.a.), co na skutek odpowiedniego stosowania przepisów k.p.a. skutkować musi uznaniem, że do decyzji w przedmiocie interwencji produktowej, będących aktami generalnymi, przepis ten może znaleźć zastosowanie na zasadzie analogii.

Zauważyć należy, iż za możliwością modyfikacji przez KNF decyzji w przedmiocie interwencji produktowej może również pośrednio przemawiać kwalifikacja tych aktów w katalogu prawnych

30. B. Wojno, [w:] Ustawa o działalności ubezpieczeniowej i reasekuracyjnej. Komentarz, [red.] M. Szczepańska, P. Wajda, Wolters Kluwer, Warszawa 2017, s. 1220-1229.

31. L. Morawski, Zasady wykładni prawa, TNOiK, Toruń 2010, s. 244-245.

32. Uchwała SN z dnia 30.01.2001 r., I KZP 50/00, LEX nr 45016.

33. E. Szewczyk, Odpowiednie stosowanie przepisów kodeksu postępowania administracyjnego w postępowaniu nadzorczym prowadzonym przez wojewodę oraz regionalnq izbę obrachunkowq, ,Studia Lubuskie” 2012, t. VIII, s. 181.

34. E. Szewczyk, M. Szewczyk, Generalny akt administracyjny, Wolters Kluwer, Warszawa 2014, s. 209-211. 
form działania administracji. W tym kontekście zwróćmy uwagę na okoliczność, że decyzję w przedmiocie zastosowania interwencji produktowej należy zaliczyć do tzw. generalnych aktów administracyjnych, podobnie jak uchwały KNF, które wydawane były na podstawie przepisów z art. 137 pkt 3-5 czy art. 141j ustawy z dnia 29 sierpnia 1997 roku - Prawo bankowe ${ }^{35}$. Wskazać przy tym należy, że wạtpliwości zarówno w doktrynie, jak i w orzecznictwie nie wywoływał fakt, że KNF posiadała kompetencję do zmiany wydawanych przez siebie uchwał. W tym zakresie słusznie przyjmowano, że KNF jako organ uprawniony do wydawania takich uchwał, tym bardziej powinna posiadać kompetencje w zakresie zmiany tych uchwał czy aktualizacji swojego stanowiska wyrażonego w uchwałach ${ }^{36}$.

W stanowiskach przedstawicieli doktryny zauważa się, że także Prezes Urzędu Regulacji Energetyki został upoważniony do wydawania generalnych aktów administracyjnych w oparciu o przepis z art. 23 ust. 2 pkt 3a ustawy z dnia 10 kwietnia 1997 roku - Prawo energetyczne ${ }^{37}$. Prezes Urzędu Regulacji Energetyki posiada kompetencję do opracowywania wytycznych i zaleceń mających zapewnić jednolitą formę planów rozwoju w zakresie zaspokojenia obecnego i przyszłego zapotrzebowania na paliwa gazowe lub energię, które to plany mają być sporządzane przez przedsiębiorstwa zajmujące się przesyłaniem lub dystrybucją paliw. W piśmiennictwie wskazuje się, że Prezes Urzędu Regulacji Energetyki uprawniony jest do modyfikacji wydanych przez siebie generalnych aktów administracyjnych w przypadku wystapienia okoliczności wpływających na poziom bezpieczeństwa energetycznego, co przemawiać będzie za koniecznością dostosowania wydanych aktów do nowej sytuacji występującej na rynku ${ }^{38}$. Trafnie podkreśla się, że organ administracyjny wydający akt administracyjny generalny posiada także kompetencję do jego zmiany. Tym samym należy przyjąć, że skoro KNF jest organem właściwym do wydania decyzji, o której mowa w art. 366 ust. 2 u.dz.u.r., to może także zmienić ten akt, w tym w szczególności dokonać zmiany terminu zawieszającego zastrzeżonego w decyzji w przedmiocie interwencji produktowej.

W systemie prawa istnieja przepisy, które stanowia podstawę do wydania przez KNF aktów administracyjnych generalnych i ich następnie zmiany. Przykładowo, KNF na postawie art. 32c ust. 8 ustawy z dnia 29 lipca 2005 roku o obrocie instrumentami finansowymi ${ }^{39}$ może dokonać zmiany postanowień wydanego aktu administracyjnego generalnego w ramach dokonywanego przez KNF przeglądu. Ustawodawca w art. 366 u.dz.u.r. nie wskazał na taką okoliczność wprost, jednakże za przyjęciem stanowiska, że KNF jest uprawniona dokonać modyfikacji decyzji w przedmiocie interwencji produktowej, przemawiają zarówno argumenty natury systemowej (powołane

35. Tekst jedn. Dz. U. 2020, poz. 1896 z późn zm.

36. Patrz np.: Uchwała Nr 319/2017 KNF z dnia 1.08.2017 r. zmieniajaca uchwałę w sprawie trybu wykonywania nadzoru nad działalnością bankową (Dz. Urz. KNF z 2017 r. poz. 15); Uchwała Nr 704/2016 KNF z dnia 27.09.2016 r. zmieniająca uchwałę KNF w sprawie ustanowienia wyróżnienia pod nazwą „Instytucja finansowa przyjazna mediacji” i zasad jego przyznawania (Dz. Urz. KNF z 2016 r. poz. 34); Uchwała Nr 172/2012 KNF z dnia 19.06.2012 r. zmieniająca uchwałę w sprawie zakresu i szczegółowych zasad wyznaczania wymogów kapitałowych z tytułu poszczególnych rodzajów ryzyka (Dz. Urz. KNF z 2012 r. poz. 8).

37. Tekst jedn. Dz. U. 2021, poz. 716 z późn. zm. Por. także: A. Szafrański, [w:] Prawo energetyczne. Ustawa o odnawialnych źródłach energii. Ustawa o rynku mocy. Ustawa o inwestycjach w zakresie elektrowni wiatrowych. Komentarz, [red.] M. Czarnecka, T. Ogłódek, CH Beck, Warszawa 2020, s. 427-522; M. Swora, D. Nowak, [w:] Prawo energetyczne. Tom II. Komentarz do art. 12-72, [red.] Z. Muras, M. Swora, Wolters Kluwer, Warszawa 2016, s. 208.

38. M. Szewczyk, E. Szewczyk, Generalny akt administracyjny, Wolters Kluwer, Warszawa 2014, s. 138.

39. Tekst jedn. Dz. U. 2021, poz. 328, z późn. zm. 
powyżej], jak i argumenty natury celowościowej. A contrario, uznanie, że KNF nie posiada kompetencji do zmiany wydanej decyzji w przedmiocie interwencji produktowej, skutkowałoby - w obliczu niemożności skorzystania tutaj z tzw. środków prawnych w reżimie ustawy k.p.a. - że KNF nie mogłaby w ogólności korygować popełnionych przez siebie błędów czy dostosowywać treści decyzji do zmieniających się okoliczności, które nie przemawiaja jednakże za tym, aby cofnać interwencję produktową. Oznaczałoby to, że raz wydana decyzja w przedmiocie interwencji produktowej musiałaby już na zawsze pozostać w obiegu. Stan taki należy natomiast uznać za niezgodny z systemową rolą decyzji w przedmiocie interwencji produktowej, która jako środek nadzoru następczego powinna być zgodna z przepisami prawa. Ponadto decyzja w przedmiocie interwencji produktowej ma czasowy charakter, na co wskazuje treść przepisu z art. 17 ust. 6 Rozporządzenia PRIIP, który przewiduje możliwość cofnięcia tej decyzji przez właściwy organ nadzoru. W efekcie, skoro decyzja z art. 17 ust. 1 Rozporządzenia PRIIP powinna podlegać cofnięciu w przypadku wyeliminowania zagrożenia występującego na rynku ubezpieczeniowym, to tym bardziej właściwy organ powinien mieć możliwość zmiany decyzji w przedmiocie interwencji produktowej w celu dostosowania jej treści do zmieniających się warunków istniejących w obrębie właściwego rynku ubezpieczeń.

Ratio normy z art. 366 ust. 3 u.dz.u.r. jest rozciągnięcie gwarancyjnej funkcji przepisów k.p.a. na sprawy, w których zostanie wydana decyzja w przedmiocie interwencji produktowej. Chodzi tutaj w istocie o zapewnienie odpowiedniego poziomu ochrony sfery praw i interesów podmiotów, do których adresowana jest decyzja KNF wydawana na podstawie art. 17 Rozporzadzenia PRIIP w związku z art. 366 u.dz.u.r. Odwołując się zatem - w celu tzw. harmonizowania kontekstów do instrumentarium wykładni celowościowej, wskażmy, że wszystkie wątpliwości w zakresie wykładni przepisu z art. 366 ust. 3 u.dz.u.r. należy interpretować przez gwarancyjny charakter norm z k.p.a. Warto także niejako na marginesie zauważyć, że w piśmiennictwie podnoszone sa głosy przemawiające za objęciem regulacją prawna generalnych aktów administracyjnych (tj. ujęciem ich w reżimie k.p.a. ${ }^{40}$. Generalne akty administracyjne stanowią istotną kategorię aktów stosowanych w praktyce działania organów administracyjnych, z uwagi na okoliczność, iż w znaczacy sposób mogạ wpływać na sytuację prawną podmiotów będących adresatami generalnych aktów administracyjnych. Z uwagi na wskazaną istotność generalnych aktów administracyjnych, jak również w ramach dążenia do realizacji zasady państwa prawnego oraz bezpieczeństwa prawnego w zakresie zwiększenia pewności prawa, akty te powinny podlegać regulacji w treści k.p.a. ${ }^{41}$.

Powyższe rozważania powinny przy tym skutkować przyjęciem, iż wszelkie wạtpliwości w zakresie istnienia uprawnienia KNF do wprowadzenia zmian w treści decyzji z art. 366 ust. 2 u.dz.u.r. należy interpretować in favorem zapewnienia ochrony dla sfery praw i interesów adresatów decyzji KNF w przedmiocie zastosowania interwencji produktowej. KNF powinna móc wprowadzić zmiany w decyzji w przedmiocie interwencji produktowej. Hipotetyczne przyjęcie odmiennego kierunku interpretacji skutkowałoby bowiem tym, że KNF nie mogłaby eliminować z obrotu prawnego wydawanych przez siebie decyzji, które stały się nieadekwatne w stosunku do zaistniałych okoliczności.

Za prawidłową należy uznać taką interpretację przepisu z art. 366 ust. 3 u.dz.u.r., która umożliwia organowi nadzoru nad rynkiem ubezpieczeniowym realizację funkcji gwarancyjnej przepisów

40. E. Szewczyk, Publikacja generalnych aktów administracyjnych na przykładzie produktów leczniczych wycofanych z obrotu, [w:] Myśl Mariana Zimmermanna a współczesne prawo administracyjne, [red.] L. Staniszewska, M. Szewczyk, J. Zimmermann, Wolters Kluwer, Warszawa 2020, s. 166-168.

41. Ibidem, s. 166-168. 
k.p.a. Pozwala to zatem na przyjęcie, że KNF powinna posiadać kompetencję do zmiany wydanej przez siebie decyzji, za czym przemawia również stanowisko wypracowane przez sądy administracyjne ${ }^{42}$. W tym kontekście za trafny należy uznać pogląd, zgodnie z którym działanie uwzględniajace interes strony w rozumieniu art. 154 k.p.a. powinno polegać na przyjmowaniu przez organ tego sposobu rozstrzygnięcia sprawy administracyjnej, który skutkować będzie zmianą decyzji mniej korzystnej dla strony na korzystniejszą, w sytuacji gdy organ ma możliwość dokonania korzystniejszego dla strony rozstrzygnięcia, które nie będzie pozostawać w kolizji z obowiązujacym porządkiem prawnym ${ }^{43}$. Oznacza to, że wydanie decyzji w przedmiocie interwencji produktowej nie może w jakimkolwiek przypadku prowadzić do nałożenia przez KNF na podmiot będący odbiorca decyzji w przedmiocie interwencji produktowej zobowiązania niemogącego podlegać wykonaniu. W świetle zasady impossibilium nulla obligatio est prawo, jego wykładnia oraz jego stosowanie nie moga prowadzić do nałożenia na adresatów obowiązków niemożliwych do realizacji ${ }^{44}$. Wprawdzie powyższa paremia wywodzi się z prawa zobowiązaniowego i nie ma w prawie publicznym normatywnego odzwierciedlenia, jednakże powinna być traktowana jako istotny element zasady praworządności oraz wskazówka interpretacyjna. Ustawodawca nie może wprowadzać rozwiązań prawnych ustanawiających obowiązki niemożliwe do wykonania, a tym bardziej wiązać z tym negatywnych dla danego podmiotu konsekwencji prawnych. Przyjęcie takiej wykładni stałoby bowiem w opozycji do jednej z zasad fundamentalnych dla całego systemu prawa zasad, tj. zasady impossibilium nulla obligatio est. W sytuacji uznania przez KNF, że realizacja całości czy części zobowiązań wynikających z treści decyzji w przedmiocie interwencji produktowej mogłaby okazać się niemożliwa do realizacji, należy przyjać, że KNF jak najbardziej będzie uprawniona do dokonania zmiany decyzji w celu wyeliminowania stanu niezgodnego z zasadą impossibilium nulla obligatio est.

Dodatkowym argumentem potwierdzającym powyższe stanowisko jest motyw 25 Preambuły Rozporządzenia PRIIP, w której to prawodawca unijny zauważył, że właściwy organ nadzorczy lub EIOPA (w ekstraordynaryjnych okolicznościach) powinien mieć prawo zapobiegawczo nałożyć zakaz lub ograniczenie wprowadzania do obrotu, dystrybucji lub sprzedaży inwestorom ubezpieczeniowego produktu inwestycyjnego, a także zaznaczając, że: „Uprawnienia te nie wiążą się z wymogiem wprowadzenia lub stosowania przez właściwy organ lub przez ElOPA zatwierdzenia produktu bądź licencjonowania ani nie zwalniają twórcy ubezpieczeniowego produktu inwestycyjnego z obowiązku spełnienia wszystkich odpowiednich wymogów określonych w niniejszym rozporządzeniu. Ponadto uprawnienia te należy wykorzystywać wyłącznie winteresie publicznym i nie powinny one prowadzić do powstania odpowiedzialności cywilnej po stronie właściwych

42. Por. np.: wyrok NSA z dnia 1.07.2021 r., sygn. II GSK 1722/18, LEX nr 3226918; wyrok WSA w Warszawie z dnia 11.12.2018 r., VII SA/Wa 795/18, LEX nr 2616590; wyrok WSA w Łodzi z dnia 17.08.2021 r., II SA/Łd 248/21, LEX nr 3229127; wyrok WSA w Lublinie z dnia 13.05.2021 r., II SA/Lu 812/20, LEX nr 3183104.

43. Wyrok NSA z dnia 29.01.2021 r., sygn. III OSK 2748/21, LEX nr 3186768; wyrok WSA w Łodzi z dnia 28.02.2018 r., sygn. III SA/Łd 1196/17, LEX nr 2459931; wyrok WSA w Gdańsku z dnia 22.12.2020 r., sygn. II SA/Gd 635/20, LEX nr 3115269; wyrok WSA w Warszawie z dnia 10.06.2014 r., sygn. I SA/Wa 2568/13, LEX nr 1564022; wyrok WSA w Warszawie z dnia 12.03.2020 r., sygn. II SA/Wa 2036/19, LEX nr 3053080; wyrok WSA w Warszawie z dnia 14.03.2019 r., sygn. IV SA/Wa 3282/18, LEX nr 3012907; wyrok WSA we Wrocławiu z dnia 5.02.2020 r., sygn. III SA/Wr 399/19, LEX nr 3099062.

44. Wyrok NSA z dnia 18.12.2020 r., sygn. I OSK 1485/20, LEX nr 3115478; wyrok NSA z dnia 30.11.2011 r., sygn. II FSK 1096/10, LEX nr 1151257; wyrok NSA z dnia 12.07.2010 r., sygn. II GSK 71/10, LEX nr 1080160. 
organów”45. W sytuacji „zmuszenia” adresatów decyzji z art. 366 ust. 2 u.dz.u.r. do realizacji niemożliwej powinności mielibyśmy właśnie do czynienia z odpowiedzialnością cywilną KNF ${ }^{46}$ z tytułu wykreowania takiego „zobowiazzania”, co jest sprzeczne z celem stosowania przez organ nadzoru instytucji interwencji produktowej i co przemawia za uznaniem, że organ nadzoru powinien posiadać możliwość zmiany wydanej decyzji w tym zakresie.

Celowym jest wskazanie, że jakkolwiek wniesienie skargi do Wojewódzkiego Sąu Administracyjnego od decyzji w przedmiocie interwencji produktoweje nie wstrzyma jej wykonalności z uwagi na okoliczność, że skarga do sądu administracyjnego nie ma charakteru bezwzględnie suspensywnego ${ }^{48}$, wobec czego zarówno KNF (co wynika z treści art. $61 \S 2$ pkt 2 ustawy z dnia 30 sierpnia 2002 roku - Prawo o postępowaniu przed sądami administracyjnymi ${ }^{49}$ ), jak i Wojewódzki Sąd Administracyjny w Warszawie (argumentum ex art. $61 \S 3$ p.p.s.a.) posiadają uprawnienie do wstrzymania wykonalności decyzji w przedmiocie interwencji produktowej. W efekcie, przyjmując rozumowanie a maiore ad minus, jak również odnosząc się do argumentacji celowościowej, zauważyć należy, że skoro KNF może wstrzymać wykonalność wydanej przez siebie decyzji, to tym bardziej powinna również być uprawniona do zmiany terminu zawieszajacego określonego w treści wydanej przez siebie decyzji w przedmiocie interwencji produktowej.

45. Motyw 25 preambuły Rozporządzenia PRIIP.

46. Z. Banaszczyk, Odpowiedzialność za szkody wyrzqdzone przy wykonywaniu władzy publicznej, CH Beck, Warszawa 2015, s. 123-164; E. Bagińska, Podstawy odpowiedzialności cywilnej krajowych organów nadzoru finansowego w świetle doświadczeń zagranicznych, „Wiadomości Ubezpieczeniowe” 2019, nr 1, s. ?-20; D. NoIan, The Liability of Financial Supervisory Authorities, „Journal of European Tort Law” 2013, No. 4, s. 211-222.

47. Wskazać należy, że adresatom decyzji w przedmiocie interwencji produktowej przysługuje możliwość zaskarżenia takiej decyzji do sądu administracyjnego. Możliwości takiej należy upatrywać w tym, że adresaci decyzji w przedmiocie interwencji prawnej posiadają interes prawny, o którym mowa w art. 50 § 1 p.p.s.a., z uwagi na okoliczność, że decyzja wywiera wpływ na sposób prowadzenia działalności przez zakłady ubezpieczeń. Ponadto decyzję w przedmiocie interwencji produktowej należy zakwalifikować jako akt z zakresu administracji publicznej dotyczący uprawnień lub obowiązków wynikających z przepisów prawa, z wyłączeniem aktów lub czynności podjętych w ramach postępowania administracyjnego określonego w ustawie k.p.a. (zgodnie $z$ art. 3 § 2 pkt 4 p.p.s.a.), wobec czego podlega on kontroli działalności administracyjnej sprawowanej przez sady administracyjne. W efekcie adresat decyzji w przedmiocie interwencji produktowej dysponuje prawem do wniesienia skargi do Wojewódzkiego Sądu Administracyjnego na tę decyzję na podstawie art. $3 \S 2$ pkt 4 p.p.s.a., ponieważ posiada w tym interes prawny, co dostrzegła także Komisja Nadzoru Finansowego w treści decyzji z dnia 15.07.2021 r. (patrz: pouczenie na s. 83 decyzji).

48. Wyrok WSA w Warszawie z dnia 25.06.2020 r., sygn. VIII SA/Wa 915/19, LEX nr 3078404; wyrok WSA w Warszawie z dnia 10.01.2020 r., sygn. VI SA/Wa 91/19, LEX nr 3010775; wyrok NSA z dnia 14.03.2017 r., sygn. II OSK 2235/15, LEX nr 2301632; wyrok WSA w Poznaniu z dnia 22.05.2015 r., sygn. II SA/Po 244/15, LEX nr 1807331; wyrok WSA w Poznaniu z dnia 10.11.2016 r., sygn. II SA/Po 445/16, LEX nr 2192353; wyrok WSA w Warszawie z dnia 7.09.2016 r., sygn. IV SA/Wa 1309/16, LEX nr 2249596; wyrok NSA z dnia 11.12.2018 r., sygn. II OSK 131/17, LEX nr 2619130; wyrok WSA w Warszawie z dnia 5.11.2015 r., sygn. IV SA/Wa 1907/15, LEX nr 2352110; wyrok WSA w Poznaniu z dnia 24.06.2015 r., sygn. II SA/Po 360/15, LEX nr 1807357; wyrok WSA w Bydgoszczy z dnia 22.04.2015 r., sygn. II SA/Bd 31/15, LEX nr 1852063; wyrok NSA z dnia 25.05.2017 r., sygn. II OSK 2445/15, LEX nr 2314782; wyrok WSA w Bydgoszczy z dnia 22.04.2015 r., sygn. II SA/Bd 48/15, LEX nr 1852147; wyrok WSA w Bydgoszczy z dnia 22.04.2015 r., sygn. II SA/Bd 32/15, LEX nr 1852065; wyrok NSA z dnia 25.05.2017 r., sygn. II 0SK 2446/15, LEX nr 2314774; wyrok WSA w Białymstoku z dnia 25.02.2014 r., sygn. II SA/Bk 984/13, LEX nr 1513273.

49. Tekst jedn. Dz. U. 2019, poz. 2325, z późn. zm.; dalej: p.p.s.a. 
Spostrzec bowiem należy, że przyjęcie wskazanego stanowiska służyć będzie realizacji funkcji gwarancyjnej normy z art. 366 ust. 3 u.dz.u.r.

Argumentem przemawiającym za możliwością zmiany terminu zawieszającego jest również stanowisko KNF wyrażone w treści decyzji z dnia 15 lipca 2021 roku, zgodnie z którym: „w przypadku pojawienia się dynamicznych wzrostów poziomu krzywej RFR organ nadzoru planuje zaproponować zmianę parametrów kryterium zyskowności. Ryzyko, iż powstaną produkty drogie i zastapią te tańsze, jest w opinii organu nadzoru niematerialne. Procesy wdrażania produktów, nawet w przypadku prostych konstrukcji produktowych, zajmują minimum trzy do sześciu miesięcy. W takim czasie organ nadzoru będzie w stanie przygotować zmiany parametrów formuły matematycznej określającej wartość produktu dla klienta" ${ }^{50}$. Wskazany fragment decyzji KNF z dnia 15 lipca 2021 roku należy odczytywać jako formę jednoznacznego potwierdzenia, że organ nadzoru dopuszcza w przyszłości możliwość zmiany treści decyzji KNF z dnia 15 lipca 2021 roku. W efekcie skoro KNF dopuściła możliwość dokonania modyfikacji o charakterze merytorycznym w treści decyzji z dnia 15 lipca 2021 roku, to tym bardziej za dopuszczalną należy uznać zmianę tej decyzji w zakresie wydłużenia terminu zawieszającego.

Powyższa konstatacja znajduje również potwierdzenie w stanowisku przedstawionym przez EIOPA. Europejski organ nadzoru nad rynkiem ubezpieczeniowym podkreślił znaczenie elastyczności w możliwości stosowania (lub nie) działań interwencyjnych przez organy nadzoru państw członkowskich. Zgodnie ze stanowiskiem EIOPA, organ nadzoru państwa członkowskiego posiada uprawnienie do uznania zasadności stosowania interwencji produktowej w sposób elastyczny. Pozwala to na uznanie, że skoro organ nadzoru państwa członkowskiego jest uprawniony do podjęcia decyzji o zastosowaniu interwencji produktowej, to jest również uprawniony do zmiany treści tej decyzji, w tym w szczególności zmiany terminu zawieszającego, o ile uzna, iż takie działanie jest zasadne i dostosowane do okoliczności występujących w ramach konkretnego sektora ubezpieczeniowego ${ }^{51}$.

Przedstawiona wyżej wykładnia jest tym bardziej trafna, jeśli weźmiemy pod uwagę okoliczność, że w świetle art. 17 ust. 6 Rozporządzenia PRIIP właściwy organ cofa zakaz lub ograniczenie, jeżeli warunki uzasadniające zastosowanie interwencji produktowej, nie mają już dłużej zastosowania. A zatem właściwy organ nadzoru, w przypadku zmiany okoliczności odnoszących się do zastosowanej interwencji produktowej, mając na uwadze zapewnienie ochrony inwestorów oraz wyeliminowanie zakłóceń w funkcjonowaniu rynku ubezpieczeniowego, uprawniony jest również do wprowadzenia modyfikacji w treści decyzji z art. 366 ust. 2 u.dz.u.r. W tym kontekście warto zauważyć, że właściwy organ nadzoru będąc kompetentny do cofnięcia zakazu lub ograniczenia w przypadku skutecznego zrealizowania celów określonych w interwencji produktowej, powinien być również właściwy w sprawach treści decyzji w przedmiocie interwencji produktowej wobec realizacji części postulatów przewidzianych w interwencji produktowej.

50. Tak: s. 78 decyzji KNF z dnia 15.07.2021 r. (sygnatura: DNM-DNMZWP.6065.79.2021) w sprawie wprowadzenia zakazu w przedmiocie wprowadzenia do obrotu, dystrybucji i sprzedaży ubezpieczeniowych produktów inwestycyjnych - umów ubezpieczenia na życie z art. 17 ust. 1 lit. a) Rozporządzenia PRIIP.

51. EIOPA, Final Report on Product Intervention Powers under the Regulation on Key Information Documents for Packaged Retail and Insurance-Based Investment Products (PRIIPs) z dnia 29.06.2015 r., EIOPA-15/569, https://www.eiopa.europa.eu/sites/default/files/publications/consultations/eiopa-15-569_final_report_on_ certain_criteria_for_product intervention_p.pdf, s. 11 [dostęp: 22.11.2021]. 
Argumentem przemawiającym za możliwością zmiany decyzji w przedmiocie zastosowania interwencji produktowej przez krajowy organ nadzoru nad rynkiem ubezpieczeniowym jest praktyka wypracowana przez właściwy dla europejskiego rynku kapitałowego organ - Europejski Urząd Nadzoru Giełd i Papierów Wartościowych. W tym kontekście zauważyć należy, że organ ten został upoważniony do podejmowania analogicznych działań interwencyjnych na rynku kapitałowym, co EIOPA w stosunku do europejskiego rynku ubezpieczeniowego. Na podstawie przepisu z art. 40 rozporządzenia Parlamentu Europejskiego i Rady (UE) nr 600/2014 z dnia 15 maja 2014 roku w sprawie rynków instrumentów finansowych oraz zmieniające rozporządzenie (EU) nr 648/2012 $2^{52}$, Europejski Urząd Nadzoru Giełd i Papierów Wartościowych wydał decyzję (UE) 2018/1466 z dnia 21 września 2018 roku w sprawie przedłużenia okresu obowiązywania oraz zmiany tymczasowego zakazu określonego w decyzji (UE) 2018/795 i dotyczącego wprowadzania do obrotu, dystrybucji lub sprzedaży opcji binarnych klientom detalicznym ${ }^{53}$. Europejski Urząd Nadzoru Giełd i Papierów Wartościowych zmienił decyzję (UE) 2018/795 z dnia 22 maja 2018 roku o tymczasowym zakazie wprowadzania do obrotu, dystrybucji lub sprzedaży opcji binarnych klientom detalicznym w Unii, zgodnie z art. 40 Rozporządzenia nr 600/2014 przez przekształcenie tymczasowego zakazu wprowadzania do obrotu, dystrybucji lub sprzedaży opcji binarnych klientom detalicznym ze skutkiem od dnia 2 października 2018 roku. W treści art. 40 Rozporzadzenia nr 600/2014 (podobnie jak w art. 17 Rozporzadzenia PRIIP) nie wskazano explicite na uprawnienie tego organu do dokonania zmiany treści decyzji czy określenia terminu obowiązywania wprowadzenia interwencji produktowej. Mając na względzie tożsame ukształtowanie procedury stosowania interwencji produktowej, warto wspomnieć, iż Europejski Urząd Nadzoru Giełd i Papierów Wartościowych we wskazanym zakresie działał w ramach władzy dyskrecjonalnej, co per analogiam znajduje zastosowanie do EIOPA oraz do poszczególnych organów nadzoru państw członkowskich stosujacych instrument interwencji produktowej na podstawie art. 17 ust. 1 Rozporządzenia PRIIP.

\section{Kwestie proceduralne dotyczące zmiany decyzji w przedmiocie interwencji produktowej}

Odnosząc się do kwestii proceduralnych dotyczących zmiany decyzji w przedmiocie, warto wskazać, że w świetle art. 17 oraz art. 18 Rozporządzenia PRIIP właściwy organ może wprowadzić w swoim państwie członkowskim lub z jego terytorium zakazy lub ograniczenia wyłącznie po skonsultowaniu tego zagadnienia z EIOPA oraz innymi organami nadzoru państw członkowskich.

Zauważyć warto, że zgodnie z art. 17 ust. 3 Rozporządzenie PRIIP właściwy organ nadzoru nie może nałożyć zakazu lub ograniczeń w ramach interwencji produktowej, jeżeli najpóźniej na jeden miesiąc przed planowanym momentem wejścia tego środka w życie nie przekaże pisemnie ${ }^{54}$ lub w inny uzgodniony przez organy sposób do wszystkich pozostałych zaangażowanych właściwych

52. Tekst jedn. Dz. Urz. UE L 173 z 12.06.2014 r., s. 84 z późn. zm.; dalej: Rozporządzenie nr 600/2014.

53. Tekst jedn. Dz. Urz. UE L 245 z 1.10.2018, s. 17.

54. Analogicznie: G. Schaeken Willemaers, Product intervention: a european perspective, [w:] Risques, crise financière et gouvernance: perspectives transatlantiques, 2013, https://dial.uclouvain.be/pr/boreal/object/ boreal:152081, s. 42 [dostęp: 22.11.2021]. 
organów ${ }^{55}$ oraz do EIOPA szczegółowych informacji dotyczących ubezpieczeniowego produktu inwestycyjnego bądź działalności lub praktyki, do których odnosi się planowane działanie; (ii) dokładnego charakteru planowanego zakazu lub ograniczenia oraz planowanego momentu jego wejścia w życie; a także dowodów, na których oparł swoją decyzję oraz na podstawie których upewnił się, że spełniony jest każdy z warunków określonych w art. 17 ust. 2 Rozporządzenia PRIIP.

KNF zobowiązana jest do zawiadomienia zaangażowanych właściwych organów oraz EIOPA o planowanej dacie wejścia w życie interwencji produktowej, co wynika z brzmienia art. 17 ust. 3 Rozporządzenia PRIIP. Obowiązek ten powstaje również w sytuacji zmiany decyzji w przedmiocie interwencji produktowej w odniesieniu do zmiany terminu zawieszającego określonego w tej decyzji. Zgodnie z art. 17 ust. 3 Rozporządzenia PRIIP „planowany moment wejścia w życie” interwencji produktowej należy rozumieć jako moment wyznaczający miesięczny termin na konsultację z EIOPA i innymi organami nadzoru, a nie moment, od którego obowiązywać będzie interwencja produktowa.

W świetle przepisu z art. 18 ust. 2 Rozporządzenia PRIIP EIOPA po otrzymaniu powiadomienia o planowanym podjęciu działań w celu zastosowania interwencji produktowej powinna wydać opinię w kwestii tego, czy zakaz lub ograniczenie są uzasadnione i proporcjonalne. Zmiany terminu zawieszającego określonego w decyzji KNF z dnia 15 lipca 2021 roku z uwagi na okoliczność, iż nie jest to element stricte merytoryczny (tj. odnoszący się do okoliczności szczegółowo uregulowanych w rozporządzeniu delegowanym Komisji (UE) 2016/1904 z dnia 14 lipca 2016 roku uzupełniajacym rozporządzenie Parlamentu Europejskiego i Rady (UE] nr 1286/2014 w odniesieniu do interwencji produktowej], jak się wydaje, nie będzie wymagać uzyskania opinii od EIOPA, co wynika w szczególności z tego, że termin wprowadzenia interwencji produktowej nie podlega opiniowaniu przez ten organ (argumentum ex art. 18 ust. 2 w związku z art. 17 ust. 3 Rozporządzenia PRIIP).

Uwzględniając okoliczność, że kwestie proceduralne dotyczące wydania (a także zmiany) decyzji w przedmiocie interwencji produktowej zostały uregulowane wyłącznie w treści art. 17 oraz art. 18 Rozporządzenia PRIIP, wskazać należy, iż organ nadzoru nad rynkiem ubezpieczeniowym zobligowany jest do podjęcia działań określonych explicite w tych przepisach w sytuacji zmiany decyzji dotyczącej wprowadzenia interwencji produktowej. Zauważyć bowiem należy, że inne, szczegółowe regulacje mające zastosowanie do zmiany decyzji nie zostały określone ani w rozporządzeniu delegowanym Komisji (UE) 2016/1904 z dnia 14 lipca 2016 roku uzupełniającym rozporządzenie Parlamentu Europejskiego i Rady (UE) nr 1286/2014 w odniesieniu do interwencji produktowej, ani w innych ogólnodostępnych dokumentach opublikowanych na stronie EIOPA.

\section{Podsumowanie}

Mając na uwadze treść przepisów zarówno prawa krajowego, jak i europejskiego, a także uwzględniając wykładnię systemową i celowościową, w tym również charakter oraz cel stosowania środka nadzoru, jakim jest interwencja produktowa, wskazać należy, że KNF upoważniona jest nie tylko do wydania decyzji w przedmiocie zastosowania tego środka, ale również do zmiany decyzji, o której mowa w art. 366 ust. 2 u.dz.u.r. W pierwszej kolejności zauważyć należy, że decyzję z art. 366 ust. 2 u.dz.u.r. należy zakwalifikować jako generalny akt administracyjny, stanowiący formę pośrednią działania organów administracyjnych, która zawiera w sobie elementy charakterystyczne 
dla aktów administracyjnych (indywidualno-konkretnych) oraz elementy właściwe dla aktów normatywnych (generalno-abstrakcyjnych).

Z przeprowadzonej analizy wynika również, że KNF jest jak najbardziej uprawniona do dokonania zmiany terminu zawieszającego określonego w treści decyzji KNF z dnia 15 lipca 2021 roku wprowadzającej zakazy wprowadzania do obrotu, dystrybucji i sprzedaży ubezpieczeniowych produktów inwestycyjnych - umów ubezpieczenia na życie, jeżeli są związane z ubezpieczeniowym funduszem kapitałowym. Za przyjęciem takiego stanowiska przemawiaja cel stosowania interwencji produktowej oraz argumenty o charakterze celowościowym, dotyczące kompetencji przyznanej właściwym organom nadzoru w art. 17 Rozporządzenia PRIIP. Przyjmując również rozumowanie a maiore ad minus, a także mając na uwadze niemożność nakazywania podmiotom zobowiązanym do stosowania się do decyzji w przedmiocie interwencji produktowej realizacji niemożliwego zobowiązania, należy wskazać, że KNF będzie uprawniona do zmiany wydanej przez siebie decyzji. Ponadto w praktyce obrotu dopuszczono możliwość zmiany generalnych aktów administracyjnych wydawanych przez KNF, a także interwencji produktowych wydawanych przez właściwe europejskie organy nadzoru.

Odnosząc się do procedury zmiany terminu zawieszającego określonego w treści decyzji w przedmiocie interwencji produktowej, zauważyć należy, że KNF uprawniona będzie do wydania niejako nowej decyzji, która zastapi decyzję KNF z dnia 15 lipca 2021 roku. W treści nowej decyzji w przedmiocie interwencji produktowej KNF powinna powtórzyć treść obowiązującej interwencji produktowej wraz z równoczesnym określeniem nowego terminu zawieszającego. KNF będzie mogła również zmienić decyzję w przedmiocie interwencji produktowej w trybie określonym w art. 154 k.p.a. (na skutek odpowiedniego stosowania przepisów k.p.a. zgodnie z art. 366 ust. 3 u.dz.u.r.), w której KNF zmieni termin zawieszający.

\section{Wykaz źródeł}

Bagińska E., Podstawy odpowiedzialności cywilnej krajowych organów nadzoru finansowego w świetle doświadczeń zagranicznych, „Wiadomości Ubezpieczeniowe” 2019, nr 1.

Banaszczyk Z., Odpowiedzialność za szkody wyrządzone przy wykonywaniu władzy publicznej, CH Beck, Warszawa 2015.

Brzuszczak P., Ferenc K., Charakter prawny aktu administracyjnego generalnego: przełom w dyskusji?, „Studia Prawnicze i Administracyjne” 2013, nr 2.

Chmielewski J., [w:] lus est a iustitia appellatum. Księga jubileuszowa dedykowana Profesorowi Tadeuszowi Wiśniewskiemu, Ereciński T., Gudowski J., Pazdan M., Tomalak M. [red.],Wolters Kluwer, Warszawa 201 ?

Chróścielewski W., Akt administracyjny generalny, Wydawnictwo Uniwersytetu Łódzkiego, Łódź 1994. Kijowski D., Generalny akt stosowania prawa w ustawodawstwie polskim, „Przegląd Legislacyjny” 2014, nr 3.

Krawczyk A., Standardy współczesnej regulacji postępowania administracyjnego, [w:] Prawo Procesowe Administracyjne. System Prawa Administracyjnego Tom 9, Hauser R., Niewiadomski Z., Wróbel A. [red.], CH Beck, Warszawa 2020.

Kulesza M., 0 tym, ile jest decentralizacji w centralizacji, a także o osobliwych nawykach uczonych administratywistów, „Samorząd Terytorialny” 2009, nr 12. 
Łańcucki J., Interwencja produktowa jako instrument ochrony konsumentów w sektorze ubezpieczeń, [w:] Ubezpieczenia we współczesnym świecie. Problemy i tendencje, Kwiecień I. [red.], Wydawnictwo Uniwersytetu Ekonomicznego we Wrocławiu, Wrocław 201 ?

Mikosz R., Zirk-Sadowski M., Granice prawa do sqdu administracyjnego w Rzeczypospolitej Polskiej,

„Zeszyty Naukowe Sądownictwa Administracyjnego" 2007.

Wiącek M., [w:] Konstytucja RP. Tom II. Komentarz do art. 87-243, Safjan M., Bosek L. [red.], CH Beck, Warszawa 2016.

Morawski L., Zasady wykładni prawa, TNOiK, Toruń 2010.

Mrozowska-Bartkiewicz B., Instytucja interwencji produktowej w Europejskim Systemie Nadzoru Finansowego, „Prawo Asekuracyjne” 2019, nr 1.

Nolan D., The Liability of Financial Supervisory Authorities, „Journal of European Tort Law” 2013, No. 4. Piotrowska A., Ochrona klientów na rynku ubezpieczeniowym. Studium publicznoprawne, Wydawnictwo Naukowe Scholar, Warszawa 2019.

Schaeken Willemaers G., Product intervention: a european perspective, [w:] Risques, crise financière et gouvernance: perspectives transatlantiques, Nurit-Pontier L., Rousseau S. [ed.], Les Éditions Thémis, Montreal 2013.

Szewczyk E., Odpowiednie stosowanie przepisów kodeksu postępowania administracyjnego w postępowaniu nadzorczym prowadzonym przez wojewodę oraz regionalna izbę obrachunkowa, "Studia Lubuskie” 2012, t. VIII.

Szewczyk E., Publikacja generalnych aktów administracyjnych na przykładzie produktów leczniczych wycofanych z obrotu, [w: ] Myśl Mariana Zimmermanna a współczesne prawo administra-

cyjne, Staniszewska L., Szewczyk M., Zimmermann J. [red.], Wolters Kluwer, Warszawa 2020. Szewczyk M., Szewczyk E., Generalny akt administracyjny, Wolters Kluwer, Warszawa 2014.

Wajda P., [w:] Prawo rynku kapitałowego. Komentarz, Wierzbowski M., Sobolewski L., Wajda P. [red.], CH Beck, Warszawa 2018.

Wojno B., [w: ] Ustawa o działalności ubezpieczeniowej i reasekuracyjnej. Komentarz, Szczepańska M., Wajda P. [red.], C.H. Beck, Warszawa 2017.

Woś T., [w:] Postępowanie sqdowoadministracyjne, Woś T. [red.], Wolters Kluwer, Warszawa 2017.

\section{Product intervention of the Polish Financial Supervision Authority under Article 17 para 1 of Regulation 1286/2014 - selected procedural and legal aspects}

The Polish Financial Supervision Authority as the supervisory authority over the insurance market has been empowered to apply a supervisory measure in the form of product intervention. It should be pointed out that due to the limited regulation of the product intervention decision in Article 17 of the PRIIPs Regulation and in Article 366 of the Act of 11 September 2015 on insurance and reinsurance activity, especially with regard to the requirements it should meet, the question arises whether the competent insurance market supervisory authority is authorised not only to issue or withdraw a product intervention, but also may amend such a decision. In this context, it is particularly interesting whether the insurance market supervisory authority has the authority to change the suspensive period specified in the content of the decision of the Polish Financial Supervision Authority dated 15 July 2021 introducing prohibitions on marketing, distribution and 
sale of insurance investment products - life insurance contracts, if they are linked to an insurance capital fund.

Key words: time limit, product intervention, procedural and legal aspects, general act, Polish Financial Supervision Authority.

DR HAB. PAWE WAJDA - profesor UW w Katedrze Prawa i Postępowania Administracyjnego na Wydziale Prawa i Administracji Uniwersytetu Warszawskiego; adwokat w kancelarii Baker \& McKenzie, w której odpowiada za obszar Financial Services Regulatory

ORCID: 0000-0003-4423-8881

e-mail: p.wajda@wpia.uw.edu.pl 
